\title{
lodine-129 Dose in LLW Disposal Facility Performance Assessments
}

by

E. L. Wilhite

Westinghouse Savannah River Company

Savannah River Site

Aiken, South Carolina 29808

J. R. Cook

W. H. Carlton

DOE Contract No. DE-AC09-96SR18500

This paper was prepared in connection with work done under the above contract number with the U.S.

Department of Energy. By acceptance of this paper, the publisher and/or recipient acknowledges the U.S. Government's right to retain a nonexclusive, royalty-free license in and to any copyright covering this paper, along with the right to reproduce and to authorize others to reproduce all or part of the copyrighted paper. 


\section{DISCLAIMER}

This report was prepared as an account of work sponsored by an agency of the United States Government. Neither the United States Government nor any agency thereof, nor any of their employees, makes any warranty, express or implied, or assumes any legal liability or responsibility for the accuracy, completeness, or usefulness of any information, apparatus, product, or process disclosed, or represents that its use would not infringe privately owned rights. Reference herein to any specific commercial product, process, or service by trade name, trademark, manufacturer, or otherwise does not necessarily constitute or imply its endorsement, recommendation, or favoring by the United States Government or any agency thereof. The views and opinions of authors expressed herein do not necessarily state or reflect those of the United States Government or any agency thereof.

This report has been reproduced directly from the best available copy.

Available to DOE and DOE contractors from the Office of Scientific and Technical Information, P. O. Box 62, Oak Ridge, TN 37831; prices available from (423) 576-8401.

Available to the public from the National Technical Information Service, U. S. Department of Commerce, 5285 Port Royal Road, Springfield, VA 22161. 


\section{DISCLAIMER}

Portions of this document may be illegible in electronic image products. Images are produced from the best available original document. 


\section{Westinghouse}

Savannah River Company

Alken, SC 29808
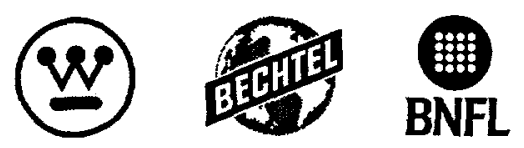

WSRC-RP-98-01352

KEYWORDS: RADIOLOGICAL DOSE

IODINE-129

LOW-LEVEL WASTE

RETENTION: Permanent

IODINE-129 DOSE IN LLW DISPOSAL FACILITY PERFORMANCE ASSESSMENTS (U)

Authors

Elmer L. Wilhite

James R. Cook

William H. Carlton

Westinghouse Savannah River Company

Savannah River Technology Center

Aiken, SC 29808

Date: December 16, 1998 
WSRC-RP-98-01352

December 16, 1998

REVIEWS AND APPROVALS

Authors
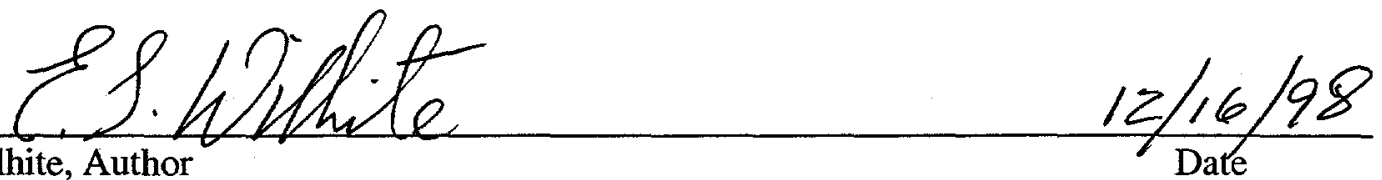

E. L. Wilhite, Author Waste Processing Technology

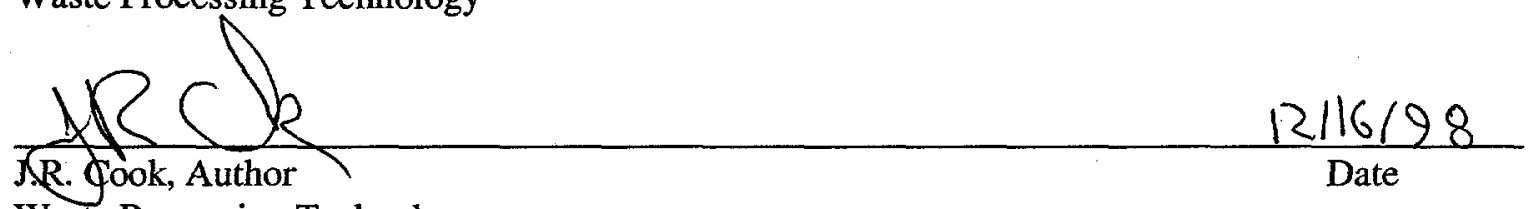
Waste Processing Technology

$\frac{12 / 16 / 98}{D a t e}$

W. H. Carlton, Author

Date

Environmental Sciences and Technology

Approvals/Reviey

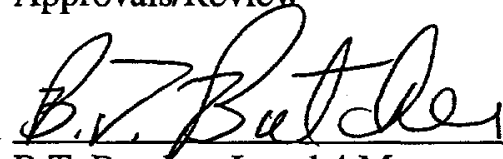

B.T. Butcher, Level 4 Manager Waste Processing Technology

Gltarem

W.E. Stevens, Level 3 Manager Waste Processing Technology
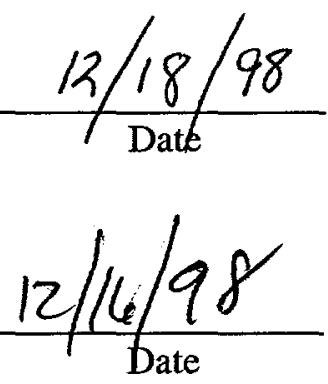

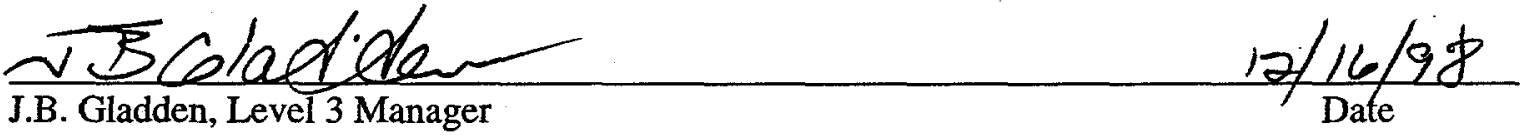

Environmental Sciences and Technology

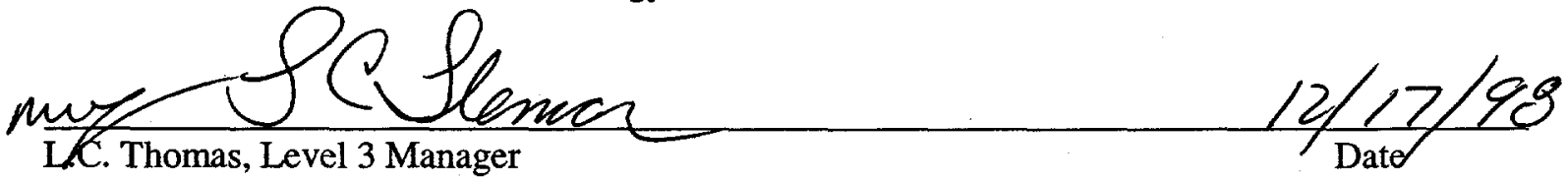
Solid Waste Division

Page 2 of 15 
WSRC-RP-98-01352

December 16, 1998

\section{SUMMARY}

Iodine-129 has the lowest Performance Assessment derived inventory limit in SRS disposal facilities. Because iodine is concentrated in the body to one organ, the thyroid, it has been thought that dilution with stable iodine would reduce the dose effects of ${ }^{129} \mathrm{I}$.

Examination of the dose model used to establish the Dose Conversion Factor for ${ }^{129}$ I shows that, at the levels considered in performance assessments of low-level waste disposal facilities, the calculated ${ }^{129} \mathrm{I}$ dose already accounts for ingestion of stable iodine. At higher than normal iodine ingestion rates, the uptake of iodine by the thyroid and the mass of the thyroid itself decrease, which effectively cancels out the isotopic dilution effect.

\section{INTRODUCTION}

Disposal of low-level radioactive waste (LLW) at DOE facilities must meet the requirements of DOE Order $5820.2 \mathrm{~A}^{1}$. DOE $5820.2 \mathrm{~A}$ specifies performance objectives and requires that a radiological performance assessment (PA) be prepared to provide reasonable assurance that the performance objectives will not be exceeded. The PA projects migration of radionuclides from the disposed waste through the environment to points of potential uptake by hypothetical future persons, calculates the dose that could be received by these persons under certain exposure scenarios, and compares the calculated doses with performance objectives. A PA for the SRS Low Level Waste Disposal Facility (LLWDF) has been prepared ${ }^{2}$. The results of the PA are used, along with other information (e.g., Safety Analysis Report) to establish limits on the amount of radionuclides that can be disposed in conformance with performance objectives ${ }^{3}$.

Iodine-129 is a fission product with a half-life of about 16 million years. It is very mobile in the environment due to its low retention in sub-surface soil. Iodine-129 has the lowest PA-derived limit on acceptable radionuclide inventory in the LLWDF'. Iodine-129 has long been considered a potentially problematic radionuclide in LLW disposal $4,5,6,7,8,9,10$.

Due to the long half-life of ${ }^{129} \mathrm{I}$, the specific activity (i.e., the radioactivity associated with a given mass of the radionuclide) is low. This, in association with the limited uptake of ingested iodine by the body, has led some to believe that potential doses from ${ }^{129} \mathrm{I}$ are inherently limited and that ${ }^{129} \mathrm{I}$ should not be considered a problematic radionuclide in LLW disposal ${ }^{11,12,13,14,15,16,17,18,19,20}$. 
WSRC-RP-98-01352

December 16, 1998

\section{DISCUSSION}

\section{Iodine Radiochemistry}

Iodine has 34 isotopes ${ }^{21}$ only one of which, ${ }^{127} \mathrm{I}$, is stable. Fourteen of the isotopes, including ${ }^{127} \mathrm{I}$, are produced in fission ${ }^{21}$. Some properties of the iodine fission product isotopes are listed in Table 1.

\begin{tabular}{|c|l|c|}
\hline \multicolumn{3}{|c|}{ Table 1. Iodine Fission Product Isotopes } \\
\hline Mass Number & Half-life & Fission yield, \% \\
\hline 127 & stable & 0.126 \\
\hline 129 & $1.57 \times 10^{7}$ years & 0.75 \\
\hline 131 & 8.04 days & 2.89 \\
\hline 132 & 2.3 hours* & 4.31 \\
\hline 133 & 20.8 hours* & 6.69 \\
\hline 134 & 52.6 minutes* & 6.87 \\
\hline 135 & 6.57 hours & 6.54 \\
\hline 136 & 1.39 minutes* & 6.32 \\
\hline 137 & 24.5 seconds & 6.19 \\
\hline 138 & 6.5 seconds & 6.71 \\
\hline 139 & 2.30 seconds & 6.4 \\
\hline 140 & 0.86 seconds & 6.21 \\
\hline 141 & 0.45 seconds & 5.8 \\
\hline 142 & $\approx 0.2$ seconds & 5.84 \\
\hline
\end{tabular}

* Isotope has two isomeric states, the longest half-life is listed

Of the iodine fission products, only ${ }^{129} \mathrm{I}$ and ${ }^{131} \mathrm{I}$ are potentially significant contributors to radiological exposure of the public from nuclear operations; the half-lives of the other isotopes are too short for them to provide appreciable exposure. Iodine-131 is important in nuclear facility operations $\mathrm{s}^{22}$ and ${ }^{129} \mathrm{I}$ is potentially significant in waste disposal. The mass of fission product iodine is comprised primarily of ${ }^{127} \mathrm{I}$ and ${ }^{129} \mathrm{I}$; every gram of ${ }^{129} \mathrm{I}$ produced in fission will be accompanied by 0.16 grams of ${ }^{127} \mathrm{I}$.

\section{$\underline{\text { Iodine Metabolism }}$}

Iodine is an essential element in the body ${ }^{23}$. Ingested or inhaled iodine is accumulated by the thyroid gland that produces the hormones thyroxin and triiodothyronine. These hormones are important for regulating the metabolic rate of the body. The amount of iodine required by the body is about $70 \mu \mathrm{g}$ per day.

Iodine can be toxic ${ }^{23}$. Exposure to iodine vapor irritates the lungs and eyes. The Occupational Safety and Health Act has established a limit on iodine concentration in air in the workplace of $0.1 \mathrm{ppm}\left(1 \mathrm{mg} / \mathrm{m}^{3}\right)^{24}$. Ingestion of iodine in amounts significantly greater than the normal dietary intake can lead to irritation of the gastrointestinal tract; ingestion of gram quantities can be fatal ${ }^{23}$. The state of Maine has set a guideline for iodide in drinking water of $340 \mu \mathrm{g} / \mathrm{L}^{25}$. 


\section{Iodine-129 Dosimetry}

To determine the radiological dose from assimilated iodine radionuclides, the metabolic processes must be simulated. The iodine metabolic model adopted by the International Commission on Radiological Protection is shown in Figure $1^{26}$. The model assumes an iodine intake of 200 $\mu \mathrm{g} /$ day. It assumes that the thyroid takes up $30 \%$ of the ingested iodine. It also assumes that the iodine in the thyroid has a biological half-life of 120 days. Data pertinent for ${ }^{129} \mathrm{I}$ dose calculations are shown in Table 2 .

Figure 1 ICRP Iodine Metabolic Model for Adults

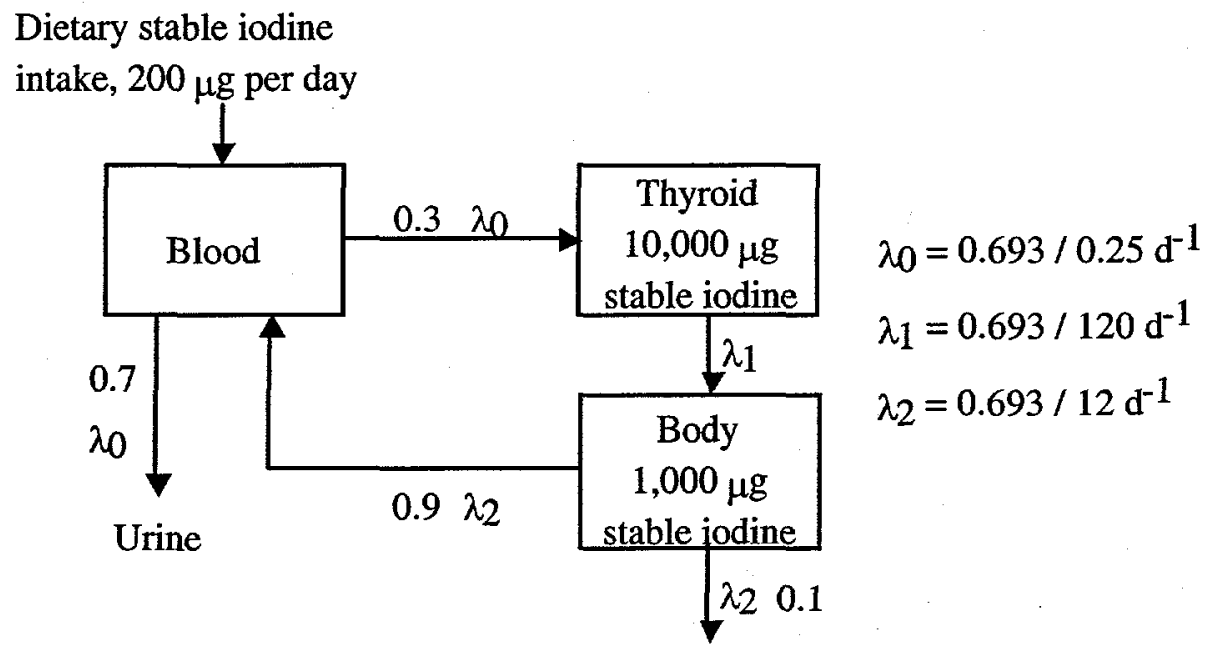

Feces

\begin{tabular}{|l|l|}
\hline \multicolumn{2}{|c|}{ Table 2. Standard Parameters for ${ }^{129} \mathrm{I}$ Dose Calculation } \\
\hline Parameter & \multicolumn{1}{|c|}{ Value } \\
\hline Radioactive half-life & $1.57 \times 10^{7}$ years $^{27}$ \\
\hline Specific Activity & $1.77 \times 10^{-4} \mathrm{Ci} / \mathrm{g}^{28}$ or $5,650 \mathrm{~g} / \mathrm{Ci}$ \\
\hline Specific Effective Energy & $0.068 \mathrm{Mev}$ per disintegration ${ }^{27}$ \\
\hline Mass of thyroid & $20 \mathrm{grams}^{29}$ \\
\hline Fractional uptake of ingested iodine by thyroid & $0.3^{30}$ \\
\hline Mass of iodine in thyroid & $10 \mathrm{mg}^{26}$ \\
\hline Thyroid dose weighting factor & $0.03^{26}$ \\
\hline Dose conversion factor & $0.28 \mathrm{Rem} / \mu \mathrm{Ci}$ intake 31,32 \\
\hline
\end{tabular}


$\underline{\text { Limiting }}{ }^{129}$ I Dose

Because of the relatively large iodine mass associated with ${ }^{129} \mathrm{I}$ and the restricted uptake of ingested iodine by the thyroid, the dose from ingested ${ }^{129} \mathrm{I}$ is inherently limited. The limiting dose would be received when every atom of iodine in the body was an atom of ${ }^{129} \mathrm{I}$. Because of the limited uptake of ingested iodine and the low specific activity of ${ }^{129} \mathrm{I}$, this situation would only happen as a consequence of prolonged intake of pure ${ }^{129} \mathrm{I}$. Assuming that the daily intake of 200 $\mu \mathrm{g}$ of iodine was all ${ }^{129} \mathrm{I}$, the dose would be calculated as follows:

$$
\begin{aligned}
& 200 \mu \mathrm{g}{ }^{129} \mathrm{I} * 10^{-6} \mathrm{~g} / \mu \mathrm{g} * 1.77 \times 10^{-4} \mathrm{Ci} / \mathrm{g} * 10^{6} \mu \mathrm{Ci} / \mathrm{Ci}=0.035 \mu \mathrm{Ci}{ }^{129} \mathrm{I} \text { ingested } / \text { day } \\
& 0.035 \mu \mathrm{Ci}{ }^{129} \mathrm{~V} / \text { day } * 365 \text { day } / \text { year } * 0.28 \mathrm{rem} / \mu \mathrm{Ci}=3.6 \mathrm{rem} / \text { year }
\end{aligned}
$$

While $3.6 \mathrm{rem} / \mathrm{year}$ is not a life-threatening dose, it is about 1,000 times greater than the groundwater protection performance objective ${ }^{2}$, which must be met for LLW disposal.

\section{Other Studies}

\section{Iodine-129, Limits to Radiologic Dose}

An earlier study ${ }^{11}$ considered the limitation of ${ }^{129}$ I dose due to the reduction of iodine uptake by the thyroid as the mass of ingested iodine increased. This effect is illustrated by calculating the dose from ingesting ${ }^{129} \mathrm{I}$ and ${ }^{131} \mathrm{I}$, assuming a constant ingestion of ${ }^{127} \mathrm{I}$ of $200 \mu \mathrm{g} /$ day. Figure 2 shows the dose, in mrem per $\mathrm{nCi}$ ingested as a function of the amount of the radionuclide ingested. The calculated dose is adjusted ${ }^{33}$ to account for the suppression of iodine uptake by the thyroid when total iodine intake exceeds $200 \mu \mathrm{g} /$ day. Iodine-131, which has a half-life of only 8 days (specific activity of $1.2 \times 10^{5} \mathrm{Ci} / \mathrm{g}$ ) does not contribute enough mass to change the daily iodine intake.

The dose per $\mathrm{nCi}$ of ${ }^{129} \mathrm{I}$ shown in Figure 2 remains constant up to about $70 \mathrm{nCi}$. Ingestion of 70 $\mathrm{nCi}$ of ${ }^{129} \mathrm{I}$ would result in a dose of $20 \mathrm{mrem}$. The performance objectives for LLW disposal ${ }^{1}$ are $4 \mathrm{mrem} / \mathrm{year}$ (groundwater protection), $25 \mathrm{mrem} / \mathrm{year}$ (all-pathways to member of public), and $100 \mathrm{mrem} /$ year (inadvertent intruder). In the LLWDF PA ${ }^{2}$, the groundwater protection performance objective of $4 \mathrm{mrem} / \mathrm{year}$ was limiting for ${ }^{129} \mathrm{I}$. Since $4 \mathrm{mrem} / \mathrm{year}$ is less than the 20 mrem inflection point derived in this study, the reduction of calculated dose to account for the mass of ingested ${ }^{129} \mathrm{I}$ would not significantly affect the dose calculated in the PA.

However, this study did not take into account the concomitant reduction in thyroid mass associated with increased iodine ingestion ${ }^{33}$. 
WSRC-RP-98-01352

December 16, 1998

Figure 2 Calculated Dose versus Amount of Radioactive lodine Ingested

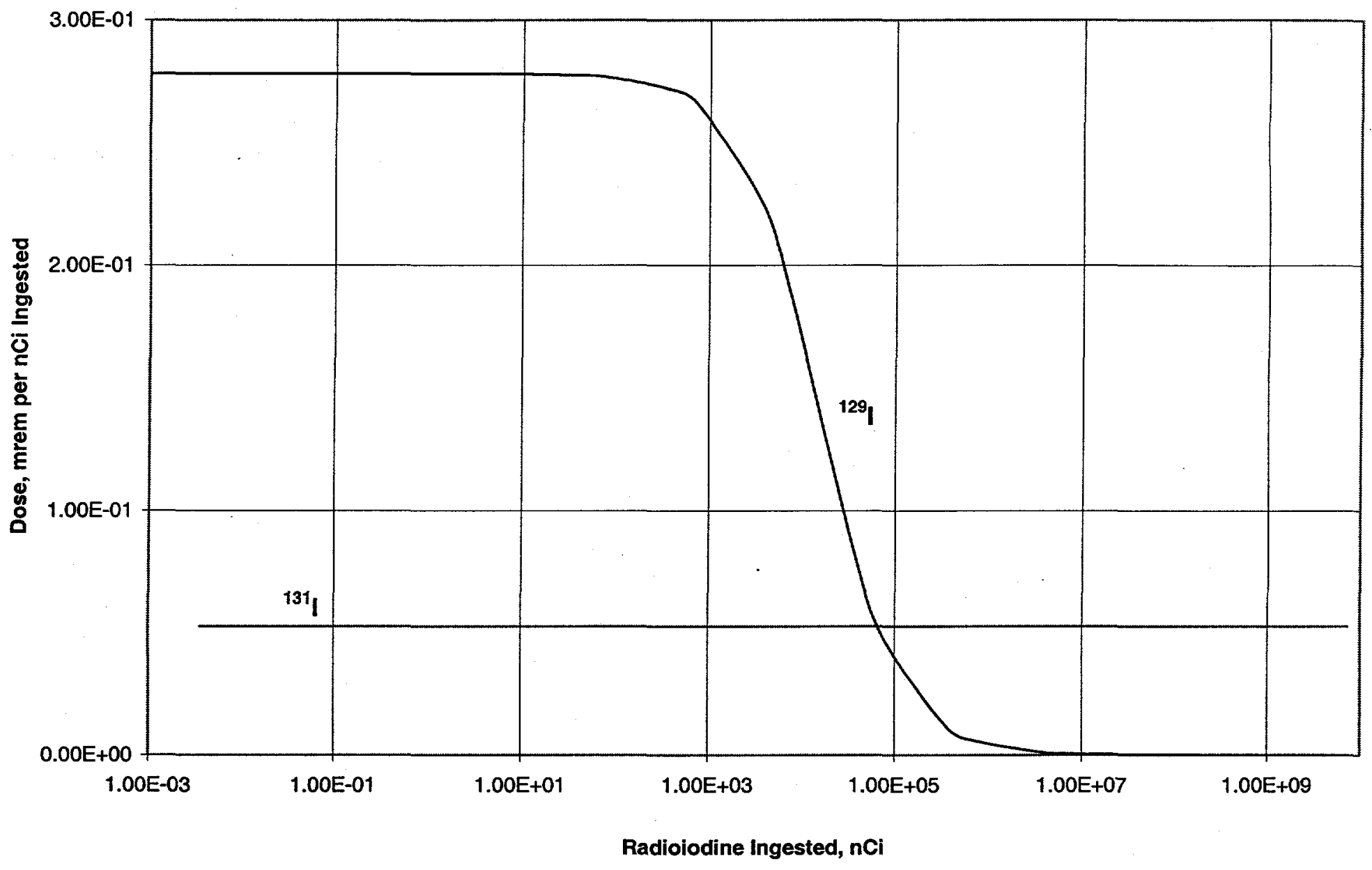

\section{Isotopic Equilibrium Analysis}

In a study of long-lived radionuclides in SRS LLW ${ }^{34}$, Cohen et al. applied isotopic equilibrium analysis (IEA) to suggest that "I-129 from SRP wastes is not a significant problem". Following, with updated ICRP information, is the argument. 
WSRC-RP-98-01352

December 16, 1998

A study of ${ }^{99} \mathrm{Tc}$ and ${ }^{129} \mathrm{I}$ in ground water near the SRS Old Burial Ground (OBG) ${ }^{35}$ showed the following results (Data from well BG-109 were omitted because the ${ }^{127}$ I value was less than the detection limit).

\begin{tabular}{|c|c|c|c|c|c|}
\hline \multicolumn{7}{|c|}{ Table 3. Iodine Analyses of SRS Groundwater } \\
\hline Well ID & PDQ-5 & BGC-2C & BGC-3C & I-13 & Geometric Mean \\
\hline${ }^{127} \mathrm{I}, \mu \mathrm{g} / \mathrm{L}$ & 1190 & 99 & 166 & 49 & 176 \\
\hline${ }^{129} \mathrm{I}, \mathrm{pCi} / \mathrm{L}$ & 12.0 & 0.033 & 0.92 & 0.006 & 0.22 \\
\hline${ }^{129} \mathrm{I}, \mu \mathrm{g} / \mathrm{L}$ & $6.8 \times 10^{-2}$ & $1.9 \times 10^{-4}$ & $5.2 \times 10^{-3}$ & $3.4 \times 10^{-5}$ & 0.0012 \\
\hline${ }^{129} \mathrm{I}^{127} \mathrm{I}$ ratio & $5.7 \times 10^{-5}$ & $1.9 \times 10^{-6}$ & $3.1 \times 10^{-5}$ & $6.9 \times 10^{-7}$ & $7.0 \times 10^{-6}$ \\
\hline
\end{tabular}

If a person's only source of iodine were this SRS groundwater, eventually all the iodine in the person's body would have the same ${ }^{129} \mathrm{~J}^{127} \mathrm{I}$ ratio as the groundwater, $7.0 \times 10^{-6}$. The resulting dose, according to the IEA method would be:

\section{$3.62 \mathrm{rem} /$ year $* 7.0 \times 10^{-6} * 1,000 \mathrm{mrem} / \mathrm{rem}=0.025 \mathrm{mrem} / \mathrm{year}$}

Although this study is interesting, the results are not pertinent to performance assessments since they are based on observed ${ }^{129} \mathrm{I}$ concentrations in groundwater rather than those calculated in the PA. It does, however, suggest that isotopic dilution may diminish doses calculated for ${ }^{129} \mathrm{I}$. In the example above, the person consumes water containing $0.22 \mathrm{pCi}^{129} \mathrm{I}$ per liter. Assuming, as in a $\mathrm{PA}$, the consumption of 2 liters of water per day, the person would consume $160 \mathrm{pCi}$ of ${ }^{129} \mathrm{I}$ in a year. Using the ${ }^{129} \mathrm{I}$ dose conversion factor of 0.28 rem per $\mu \mathrm{Ci}$ and converting units, the dose would be $0.045 \mathrm{mrem} /$ year. This suggests that, taking into account the dilution of ${ }^{129} \mathrm{I}$ by stable iodine, the dose would be reduced by about a factor of 2 .

\section{Dietary Intake of Stable Iodine and Some Aspects of Radioiodine Dosimetry}

Zvonova ${ }^{33}$ showed that the uptake of iodine by the thyroid decreased as the dietary intake increased. Her study also showed that thyroid sizes measured in different geographic locations varied inversely with the quantity of iodine in the diet. Zvonova's ${ }^{33}$ data are shown in Figure 3. At an iodine intake of $\mathbf{2 0 0}$ micrograms per day, the data in Figure 3 show that the iodine uptake by the thyroid would be about $30 \%$ and the thyroid mass would be about 20 grams; these values are consistent with the values used by the ICRP in calculating dose from radioisotopes of iodine.

As a first approximation, iodine intake of $200 \mu \mathrm{g} /$ day results in a thyroid mass of 20 grams, while an iodine intake of $400 \mu \mathrm{g} /$ day results in a thyroid mass of 10 grams. The radiological dose from ${ }^{129} \mathrm{I}$ is due almost entirely to a low energy beta particle that has a very short range in tissue; thus, the dose is deposited only in the thyroid tissue. Since the dose is derived from the energy deposited in a particular mass of affected tissue, it is dependent upon the concentration of iodine in the thyroid and remains constant over a reasonable range of iodine intake.

The radiation dose due to ${ }^{129} \mathrm{I}$ is largely independent of the quantity of iodine in the diet. This conclusion was supported in a personal communication with a recognized expert ${ }^{36}$. 
WSRC-RP-98-01352

December 16, 1998

Figure 3 lodine Uptake by Thyroid and Thyroid Mass vs lodine Intake

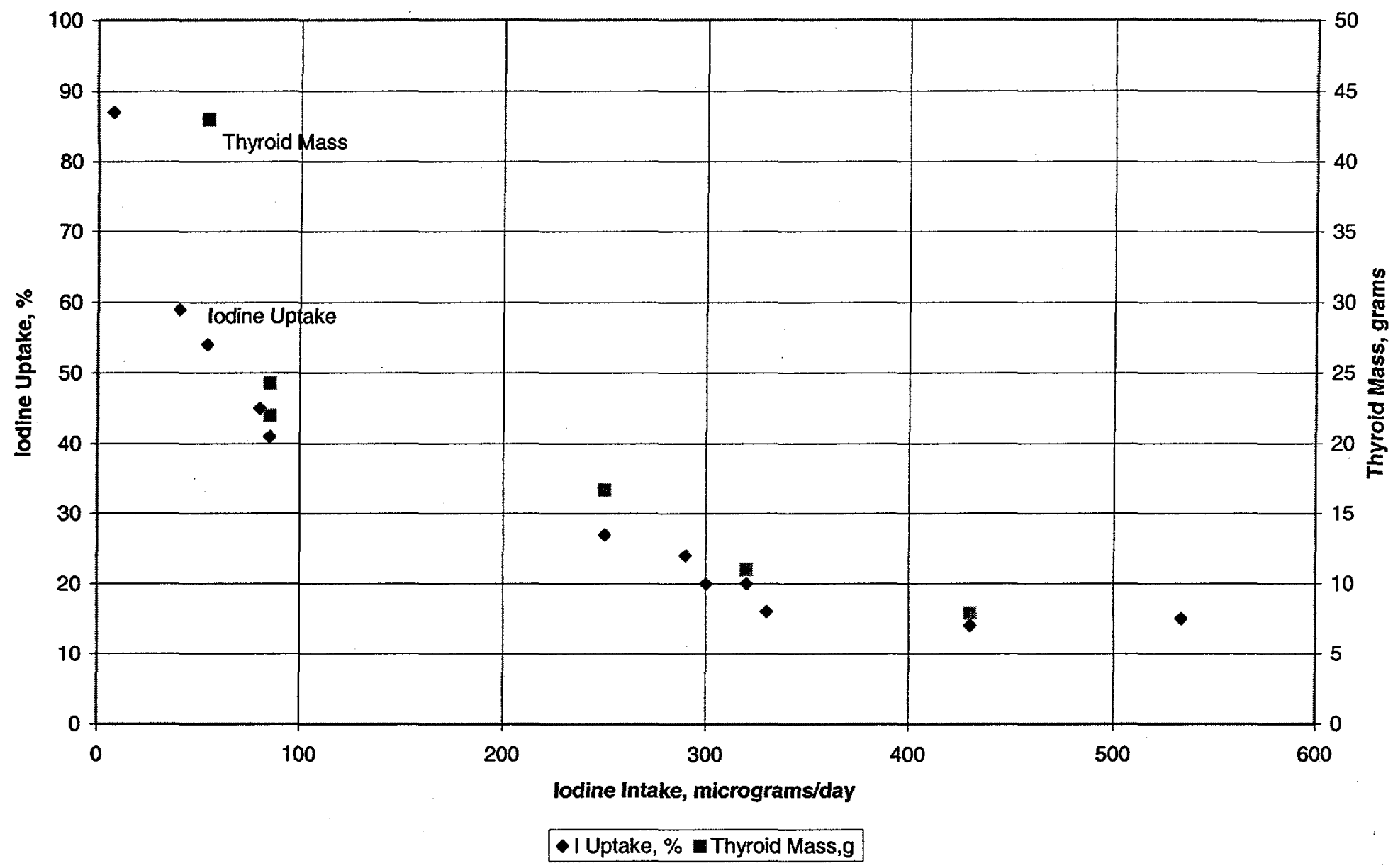

Isotopic Dilution of ${ }^{129} \mathrm{I}$

Physiological processes cannot discriminate between radioisotopes of iodine. Thus, assuming chemical equilibrium between iodine released from disposed waste and iodine present in the groundwater (i.e., all of the iodine is in the same chemical form), the iodine taken up by the thyroid from ingested groundwater will have the same isotopic (i.e., ${ }^{129} \mathrm{I} /{ }^{127} \mathrm{I}$ ) mass ratio as that in the groundwater. Assuming long-term ingestion of the groundwater, and the groundwater is the predominant source of iodine in the diet (i.e., the assumptions in performance assessments of disposed LLW) the iodine in the thyroid would eventually have the same isotopic mass ratio as the groundwater. 
WSRC-RP-98-01352

December 16, 1998

The dose from ingestion of ${ }^{129} \mathrm{I}$ can be expressed as the isotopic mass ratio of ${ }^{129} \mathrm{I}$ to the total iodine ingested in a year. The standard metabolic parameters (i.e., daily ingestion of $200 \mu \mathrm{g}$ iodine, fraction of ingested iodine taken up by the thyroid of 0.3 , dose conversion factor of 0.28 rem per $\mu \mathrm{Ci}{ }^{129}$ I ingested) from Table 2 are assumed. Table 4 shows selected values.

\begin{tabular}{|c|c|c|c|}
\hline \multicolumn{5}{|c|}{ Table 4. ${ }^{129} \mathrm{I}$ Dose and Isotopic Mass Ratio } \\
\hline Dose, mrem & $\mu \mathrm{Ci}^{129} \mathrm{I}$ ingested & $\mu \mathrm{g}^{129} \mathrm{I}$ ingested & $\mathrm{g}^{129} \mathrm{I}$ per g I \\
\hline 0.01 & $3.6 \times 10^{-5}$ & 0.2 & $2.8 \times 10^{-6}$ \\
\hline 0.025 & $8.9 \times 10^{-5}$ & 0.5 & $6.9 \times 10^{-6}$ \\
\hline 0.1 & $3.6 \times 10^{-4}$ & 2.0 & $2.8 \times 10^{-5}$ \\
\hline 1 & $3.6 \times 10^{-3}$ & 20. & $2.8 \times 10^{-4}$ \\
\hline 2 & $7.1 \times 10^{-3}$ & 40. & $5.5 \times 10^{-4}$ \\
\hline 3 & $1.1 \times 10^{-2}$ & 60. & $8.3 \times 10^{-4}$ \\
\hline 4 & $1.4 \times 10^{-2}$ & 81. & $1.1 \times 10^{-3}$ \\
\hline 10 & $3.6 \times 10^{-2}$ & 200 & $2.8 \times 10^{-3}$ \\
\hline 20 & $7.1 \times 10^{-2}$ & 400 & $5.5 \times 10^{-3}$ \\
\hline 30 & $1.1 \times 10^{-1}$ & 600 & $8.3 \times 10^{-3}$ \\
\hline
\end{tabular}

This analysis suggests that, if the disposed waste has an isotopic mass ratio of ${ }^{129} \mathrm{I}$ of less than $0.001 \mathrm{~g}{ }^{129} \mathrm{I}$ per gram of iodine, the dose, in the drinking water scenario, from ${ }^{129} \mathrm{I}$ cannot exceed 4 $\mathrm{mrem} /$ year. For example, a dose of $4 \mathrm{mrem} /$ year, calculated via the drinking water scenario, requires that the water contain $20 \mathrm{pCi}^{129} \mathrm{I}$ per liter. This is equivalent to $0.1 \mu \mathrm{g}{ }^{129} \mathrm{I}$ per liter. The drinking water scenario assumes that a person consumes 2 liters of water per day for a year. The ICRP metabolic model for iodine assumes a daily ingestion of $200 \mu \mathrm{g}$ of iodine, or, in the drinking water scenario, a water concentration of $100 \mu \mathrm{g}$ iodine per liter. Thus, in this example, the ${ }^{129} \mathrm{I}$ isotopic mass ratio is 0.001 .

This isotopic dilution, however, will not affect doses from ${ }^{129} \mathrm{I}$ calculated in a PA, if the constraints of the iodine metabolic model are adhered to. Assume the isotopic mass ratio in groundwater were $2.8 \times 10^{-4}$, per table 4 this would be commensurate with a dose of $1 \mathrm{mrem} /$ year. Also assume the groundwater contained $0.1 \mu \mathrm{g}{ }^{129} \mathrm{I}$ per liter, commensurate with a dose of 4 mrem/year. Thus, the groundwater would contain $357 \mu \mathrm{g}$ of iodine per liter. The drinking water scenario requires that the person consume 2 liters of water per day. The ingested water would contain $714 \mu \mathrm{g}$ of iodine. Because this is several times greater than the normal daily ingestion of $200 \mu \mathrm{g}$, the absorption of iodine by the thyroid will decrease, as shown by Zvanova ${ }^{33}$. Assuming a linear proportionality, the fraction of ingested iodine absorbed by the thyroid would be about 0.08 . In other words, over the span of the year's ingestion of groundwater, the thyroid would take up

$$
0.1 \mu \mathrm{g}{ }^{129} \mathrm{I} / \mathrm{L} * 2 \mathrm{~L} / \text { day } * 365 \text { day/year } * 0.08=5.8 \mu \mathrm{g}{ }^{129} \mathrm{I}
$$


WSRC-RP-98-01352

December 16, 1998

This is only $27 \%$ of the ${ }^{129} \mathrm{I}$ taken up by the normal thyroid to yield a dose of $4 \mathrm{mrem} / \mathrm{year}$. However, the increased iodine ingestion not only decreases the iodine uptake by the thyroid, it also causes the thyroid mass to decrease. Again, according to Zvanova's data, assuming a linear proportionality, the decrease in thyroid mass would be equivalent to the decrease in iodine uptake. Therefore, the calculated dose from ${ }^{129} \mathrm{I}$ would be the same. This demonstrates that isotopic dilution cannot be used to reduce doses calculated for ${ }^{129} \mathrm{I}$ in a PA.

\section{Conclusion}

The above analyses show that the maximum dose from ${ }^{129}$ I ingestion is limited by the isotope's low specific activity. However, they also demonstrate that, at the relatively low levels of ${ }^{129} I$ ingestion addressed in a PA, isotopic dilution does not limit the dose from ${ }^{129} \mathrm{I}$. Thus, adjustment of ${ }^{129} \mathrm{I}$ dose calculated in a PA to account for isotopic dilution is not appropriate. 
WSRC-RP-98-01352

December 16, 1998

References

1. U.S. Department of Energy, Order 5820.2A, Radioactive Waste Management, 1988.

2. Westinghouse Savannah River Company, Radiological Performance Assessment for the EArea Vaults Disposal Facility, WSRC-RP-94-218, 1994.

3. Westinghouse Savannah River Company, Waste Acceptance Criteria, Procedure WAC 3.17.

4. Conceptual Design Report, Alternative Concepts for Low Level Radioactive Waste Disposal, Rogers and Associates Engineering Corporation, June 1987.

5. A.K. Bhattacharyya and R. Janati, Safety Issues Related to Disposal of I-129 in a Low Level Radioactive Waste Repository, Ninth Annual DOE Low Level Radioactive Waste Management Conference, Denver, CO (August 1987).

6. Radiological Significance and Management of Tritium, Carbon-14, Krypton-85, Iodine-129 Arising from the Nuclear Fuel Cycle, Report by an NEA Group of Experts, 1980.

7. Treatment, Conditioning and Disposal of lodine-129, Technical Report Series No. 276, IAEA, 1987.

8. J.K. Soldat, Radiation Doses from Iodine-129 in the Environment, Health Physics, Vol. 30, pp. 61-70, 1976.

9. D.C. Kocher, A Dynamic Model of the Global Iodine Cycle and Estimation of Dose to the World Population from Releases of Iodine-129 to the Environment, Environment International, Vol. 5, pp. 15-31, 1981.

10. D.C. Kocher, $A$ Validation Test of a Model for Long-Term Retention of ${ }^{129}$ I in Surface Soils, Health Physics, Vol. 60, pp. 523-531, 1991.

11. S.A. Book, Iodine-129: Limits to Radiologic Dose, Health Physics, Vol. 32, pp. 321-324, 1977.

12. National Council on Radiation Protection and Measurement, Iodine-129 Evaluation of Releases from Nuclear Power Generation, NCRP Report No. 75, 1983.

13. National Council on Radiation Protection and Measurement, Induction of Thyroid Cancer by Ionizing Radiation, NCRP Report No. 80, 1985.

14. B.L. Cohen, The Origin of I in Soil and the ${ }^{129}$ I Problem, Health Physics, Vol. 49, pp. 279 285, 1985.

15. W.J. Bair, et al., Effect of $I^{127}$ on Thyroid Uptake of Inhaled $I^{131}$, Health Physics, Vol. 9, pp. 1399-1410, 1963.

16. P.M. Bryant, Derivation of Working Limits for Continuous Release Rates of ${ }^{129}$ I to Atmosphere, Health Physics Vol. 19, pp. 611-616, 1970. 
WSRC-RP-98-01352

December 16, 1998

17. S.A. Book, et al., Thyroidal Burdens of ${ }^{129}$ I from Various Dietary Sources, Health Physics, Vol. 32, pp. 143-148, 1977.

18. S.A. Book, Iodine-129 Uptake and Effects of Lifetime Feeding in Rats, Health Physics Vol. 45 , pp. 61-66, 1983.

19. S.V. Kaye and D.J. Nelson, Analysis of Specific-Activity Concept as Related to Environmental Concentration of Radionuclides, Nuclear Safety, Vol. 9, pp. 53-58, 1968.

20. J.M. Palms, et al., The Environmental Impact ${ }^{129}$ I Released by a Nuclear Fuel-Reprocessing Plant, Nuclear Safety, Vol. 16, pp. 593-602, 1975.

21. Chart of the Nuclides, Fourteenth Edition, 1989.

22. Protection of the Thyroid Gland in the Event of Releases of Radioiodine, NCRP Report No. $55,1977$.

23. H.G. Seiler and H. Sigel, Handbook on Toxicity of Inorganic Compounds, 1987.

24. Code of Federal Regulations, 29, 1910.1000, Table Z-1, July 1, 1996.

25. M.Sittig, Handbook of Toxic and Hazardous Chemicals and Carcinogens, Third Ed., 1991.

26. International Commission on Radiological Protection, Limits for Intakes of Radionuclides by Workers, ICRP Publication 30, Part 1, 1979.

27. International Commission on Radiological Protection, Radionuclide Transformations Energy and Intensity of Emissions, ICRP Publication 38, 1983.

28. B. Shleien, Handbook of Health Physics and Radiological Health, 1998.

29. International Commission on Radiological Protection, Report of the Task Group on Reference Man, ICRP Publication 23, 1974.

30. International Commission on Radiological Protection, Limits for Intakes of Radionuclides for Workers, ICRP Publication 30, Supplement to Part 1, 1979.

31. U.S. Department of Energy, Internal Dose Conversion Factors for Calculation of Dose to the Public, DOE/EH-0071, 1988.

32. K.F. Eckerman, et al., Limiting Values of Radionuclide Intake and Air Concentration and Dose Conversion Factors for Inhalation, Submersion, and Ingestion, Federal Guidance Report No. 11, 1988.

33. I.A. Zvonova, Dietary Intake of Stable Iodine and Some Aspects of Radioiodine Dosimetry, Health Physics, Vol. 57, pp. 471-475, 1989.

34. J.J. Cohen, et al., Assessment of Long-Lived Radionuclides in the Savannah River Plant Radioactive Waste Burial Grounds, SAIC-89/1080, 1989. 
WSRC-RP-98-01352

December 16, 1998

35. S.B. Oblath, Technetium-99 and Iodine-129 in the Burial Ground Plume, DPST-86-278, 1986.

36. K.F. Eckerman, Telephone Conversation, October 15, 1998. 
WSRC-RP-98-01352

December 16, 1998

WESTINGHOUSE SAVANNAH RIVER COMPANY

SAVANNAH RIVER TECHNOLOGY CENTER

December 16, 1998

Distribution:

B.T. Butcher, 773-43A

L.B. Collard, 773-43A

D.G. Collins, $241-246 \mathrm{H}$

D.P. Diprete, 773-A

A. Gibbs, 724-21E

J.B. Gladden, 773-42A

W.T. Goldston, 705-3C

R.A. Hane, 773-43A

T. Hang, 773-43A

H.Holmes-Burns, 724-9E

P.D. Hunt, 705-3C

M.W. Lewis, 724-7E

C.W. McVay, 704-43H

W.A. Morrison, 724-7E

L.M. Papouchado, 773-A

L.E. Rykken, 705-3C

R.M.Seaborn, 705-3C

D.F. Sink, 724-15E

J.W. Smith, 724-7E

W.E. Stevens, 773-A

D.J. Swale, 724-7E

W.L. Tamosaitis, 773-A

L.C. Thomas, 724-7E

A.W. Wiggins, 241-246H

J.E. Young, 773-A 